\title{
PRVA PRIZRENSKA LIGA KAO PUTOKAZ POLITIČKOG NASILJA NAD SRBIMA U STAROJ SRBIJI
}

\author{
Radoslav Gaćinović" \\ Institutu za političke studije u Beogradu
}

Nikada na prostorima Kosova i Metohije nije bilo elemenata albanske državnosti. Granice sa susedima nije određivala Srbija, već međunarodna zajednica na osnovu etničke strukture stanovništva i turskih deftera. Te granice su određene na Londonskoj konferenciji 1913. godine, a revizijom su konačno potvrđene na konferenciji u Firenci 26. jula 1926. godine. Srbi imaju ustavno i istorijsko pravo na Kosovu i Metohiji, koje je uvek starije od etničkog prava, a i međunarodno pravo je na strani Srbije, jer Povelja OUN zabranjuje nasilno otimanje delova suverenih zemalja. Brojnost jedne nacionalne zajednice se ne određuje njenim brojnim stanjem u okviru jednog dela države, već njenim brojnim stanjem u okviru cele države, pa i na osnovu tog kriterijuma Albanci su nacionalna manjina u Srbiji. Nigde u svetu do sada nacionalna manjina nije imala pravo na svoju državu. Jedna nacionalna zajednica ne može sama za sebe određivati da li je narod ili nacionalna manjina. Pored ovih pravnih činjenica treba posebno istaći da Kosovo i Metohija predstavlja centar srpske duhovnosti i kulture. Naučna istraživanja tokom XIX i XX veka utvrdila su da na Kosmetu postoje 162 objekta, koji su danas proglašena za kulturno dobro od izuzetne važnosti, dok je 500 objekata zaštićeno kao spomenici kulture, a više od 1.400 je evidentirano kao kulturna baština Srpskog naroda na tom tlu.

Ključne reči: Kosovo i Metohija, Prizrenska liga, Nasilje, Proterivanje, Stara Srbija

Odreći se slobode znači odreći se svega ljudskog: dostojanstva, ljudskih prava pa čak i svojih dužnosti.

Žan Žak Ruso

\section{Uvod}

$\mathrm{N}$ a Kosovsko-Metohijskim prostorima „nema nikakve državne tvorevine albanskog naroda, niti se neka značajna etnička skupina Albanaca ili albanskih predaka javlja u XX veku kao istorijski činilac." Srpskom narodu je u stvari svejedno da li su Albanci potomci

* Prof. dr Radoslav Gaćinović je naučni savetnik.

${ }^{1}$ D. Bogdanović, Knjiga o Kosovu, Narodna knjiga i Vojnoizdavački zavod, Beograd, 1999, str. 32. 
Ilira ili Tračana ili Pelazga, ali nije svejedno ako oni u suštini i rasističkim metodama ugrožavaju biće i pravo Srpskog naroda na Kosovo i Metohiju, i time žele da se istorija preokrene „s noga na glavu“ i vrati za vekove unazad. ${ }^{2}$ Poznato je da Srbi, dolaskom u VII veku nastanjuju prostore tadašnjeg Vizantijskog carstva i obrazuju svoje oblasti zvane „Sklavinije“, i zatim od Vizantije primaju Hrišćanstvo, a onda stvaraju svoje lokalne kneževine (od IX do XI veka) kojih je bilo nekoliko do stupanja na scenu slavne porodice Nemanjića, polovinom XII veka. Stefan Nemanja prvi uspeva da, ratujući ali i sklapajući mir sa Vizantijom, organizuje samostalnu Srpsku državu pri kraju XII veka, i tada Kosovo i Metohija ulaze u sastav srpske države, da bi odmah postali i njen središnji državni i crkveni deo. O ulasku Kosova i Metohije u sastav samostalne Srpske države jasno svedoči n Nemanjino Žitije, koje je napisao Sveti Sava na početku XIII veka. Teritorije Kosova i Metohije su, zahvaljujući plodnosti, gustoj naseljenosti i povoljnim komunikacijama, vrlo rano postale središte Srpske države. Pomeranje njenog težišta iz Rasa $^{3}$ na Kosovo potvrđuju naročito vladarske rezidencije i promene u crkvenoj organizaciji. Kao i savremenici u mnogim drugim evropskim zemljama vladari Srbije nisu tada imali jednu stalnu prestonicu, već više dvorova u kojima su povremeno boravili, primali strane poslanike, okupljali državni sabor itd. Ras je početkom XIII veka napušten i postepeno zapostavljen, dok glavnu ulogu u političkom životu dobijaju Prizren, i dvorovi na Kosovu: Pauni, Radimlja-Nerodimlja, Štimlja, Svrčin, Petrič, a u Milutinovo i Dušanovo vreme i Priština, koja je bila ne utvrđeno naselje. ${ }^{4}$ Prizren i Lipljan, bili su sedišta crkvenih Episkopija u Vizantiji. Kada su Turci zauzeli Kosovo i Metohiju (1455. godine, padom Novog Brda) i susedne krajeve, popisali su na njima zatečeno stanovništvo koje je bilo skoro Srpsko, sa svega 2-3 \% Arbanasa zapadno od Đakovice. ${ }^{5} \mathrm{U}$ srednjem veku nije postojalo posebno ime za ovu pokrajinu, osim opšteg imena Srbija. Pod ovim imenom teritoriju Kosova i Metohije pominju putopisci u XVI i XVII veku, od kojih su neki i Arbanasi. Mletački poslanik Jakov Soranco, 1575. godine kaže kako prelazeći Drim ulazi u Srbiju. ${ }^{6}$ Arhibiskup barski Marin Bici (Marin Bizzi) 1610. godine, takođe uzima Crni Drim kao granicu između Arbanije i Srbije. ${ }^{7}$ Petar Mazarski, apostolski vizitator, inače Arbanas, 1623. godine, kaže da Drim deli Arbaniju od Srbije. ${ }^{8}$ Nadbiskup Đorđe Bijanki vršeći kanonsku vizitaciju u Srbiji 1638 godine napisao je izveštaj u kome naglašava da se Prizren nalazi u Donjoj (južnoj) Srbiji (Servia, „inferiore"). ${ }^{9}$ Prema pisanim izvorima, Kosovo i Metohija i drugi krajevi današnje Kosmetske pokrajine bili su u XIII, XIV, XV i XVIII veku etnički naj homogenije oblasti srpske države. To znači

\footnotetext{
${ }^{2}$ Priština je bila centar srednjovekovne srpske feudalne države za vreme kralja Milutina /1282-1321/, a jedno vreme Prizren je bio prestonica srpskih careva Dušana i Uroša. Osim toga, grad Peć je u dva vremenska perioda od 1346-1457. i od 1557-1766. godine bio sedište Patrijaršije srpske crkve, koja je odigrala značajnu ulogu $\mathrm{u}$ istoriji Srba pre i posle okupacije Balkana od strane Turske imperije. (Radoslav Gaćinović, Otimanje Kosova $i$ Metohije, Novinsko-izdavački centar „Vojska“, Beograd, 2004, str. 7).

${ }^{3}$ Ras nije današnja Raška, kako misli naručeni NATO istoričar Noel Malkolm (Noel Robert Malcolm), nego je to današnji Novi Pazar, gde je crkva Sv. Ap. Petra i Pavla, gde je Nemanja kršten. (Memorandum o Kosovu $i$ Metohiji svetog arhijerejskog sabora srpske pravoslavne Crkve, Beograd, 2003. g. str. 19).

${ }^{4}$ Isto.

${ }^{5}$ Naučni Demografski zbornik: „Naselja i stanovništvo oblasti Brankovića 1455. godine“, urednik akademik M. Macura, Beograd /SANU 2001. god. str. 793.

${ }^{6}$ Rad Jugoslovenske akademije znanosti i umjetnosti, knj. CXXIV, s. 30.

${ }^{7}$ Starine Jugoslovenske akademije znanosti i umjetnosti, knj. XX, s. 121.

${ }^{8}$ Starine Jugoslovenske akademije znanosti i umjetnosti, knj. XXXIX, s. 28.

${ }^{9}$ Jovan Radonić, Rimska kurija u južnoslovenskim zemljama od XVI - XIX veka, Beograd 1950. godine, str. 100.
} 
da na Kosmetu nije bilo drugih narodnosti sem Srba. ${ }^{10}$ Posebno treba istaći da naziv Kosovo, nametnut od strane komunističkog režima, posle 1968 godine umesto dotadašnjeg punog naziva Kosovo i Metohija, nije adekvatan za teritoriju koja se pod tim nazivom podrazumeva. ${ }^{11}$ Na početku XXI veka je potpuno jasno da je komunističko i šiptarsko namerno potiskivanje i brisanje imena Metohija iz naziva ove srpske Pokrajine bilo u funkciji unapred predviđenih zamisli, tj. zaboravljanje, negiranje srpskog crkvenog karaktera ove oblasti, homogenizacija čitave Pokrajine, te olakšavanje njenog pretvaranja u republiku i daljeg otcepljenja od Srbije. To je bio metod za svođenje Srbije na pretkumanovsku Srbiju, u stvari na Beogradski pašaluk iz doba turskog ropstva. Dakle, Kosovo i Metohija su bili i ostali najstarije i centralne oblasti Srpskog naroda i njegove države i crkve, pa su se zato nazivali i nazivaju Stara Srbija. ${ }^{12}$ Albanci su deo jednog nad kavkaskog plemena, zvanog Albani, sličnog Degestancima i po krvi i po jeziku. ${ }^{13}$

\section{Brutalno nasilje Albanaca nad Srbima u Staroj Srbiji}

Prvi doseljenici Šiptari su počeli stizati na Kosmet 1754. godine, a intenzivnije doseljavanje se odvijalo u drugoj polovini XIX veka. Pošto su primili islam, oni su favorizovani od strane Turaka i počeli su da progone srpski živalj. Sprovodili su neviđeno nasilje i tor-

\footnotetext{
${ }^{10}$ Akademik Milisav V. Lutovac, Glas CCLXXXII Srpske akademije nauka i umetnosti, knjiga 34/1972, str. 8.

${ }^{11}$ Samo je u potonjem periodu turskog ropstva bio dat naziv „Kosovski vilajet“ - „vilajet“ je zamenio ranije turske administrativne jedinice nazivane po gradovima - ali je taj vilajet tada obuhvatao teritoriju mnogo širu od današnjeg Kosova i Metohije, tj. još i Novopazarski sandžak sa Gornjim Polimljem, severnu Makedoniju do Velesa i istočnu Makedoniju sa celim slivom reke Bregalnice. (Memorandum o Kosovu i Metohiji svetog arhijerejskog sabora srpske Pravoslavne crkve, Beograd, 2003. godine str. 7).

${ }^{12}$ Stara Srbija je oblast u koju spada Raška oblast („Novopazarski sandžak“ u tursko doba) tj. zemljište od južne bosanske granice do Kosovske Mitrovice, Kosovo Polje, Priština, Metohija sa varošima Peć, Đakovica i Prizren, i takođe neke oblasti južno od Šar-planine do Tetova i Velesa. Karakteristično je, međutim, da se na kartama koje se i danas u Albaniji štampaju i proturaju po svetu kao propagandni materijal, ime „Kosova“ upotrebljava još šire: za delove Srbije istočno od Kosova (tkz. od Šiptara „Istočno kosovo"), delove Crne Gore i Makedonije, u kojima danas ima albanskog življa, te se tako iskazuju pretenzije i na te krajeve, sa ciljem stvaranja „Velike Albanije“ mada ni Kosovo ni Metohija ni svi ovi pomenuti krajevi nikada nisu bili albanski, niti sastavni deo Albanije, niti su bili većinski naseljeni Šiptarima. Treba istaći da su nazivi Šiptar i Šćipnija izvorna, autohtona imena samih Albanaca i Albanije, na njihovom materinjem jeziku, kako oni sami sebe uvek zovu. Komunisti, a pre svega albanski, nametali su Srbima da Šiptare na Kosmetu ne smeju zvati tako, jer je to tobože „pogrdan naziv", nego da ih zovu Albancima, čime se sugerisalo da je ta teritorija albanska. (Isto, str. 8).

${ }^{13}$ Prilikom doseljavanja Albanci su ostali u srednjoj Albaniji /Shipnial, a pošto su imali veliki priraštaj njihovo brojno stanje je brzo raslo. Njihov najveći junak Đurađ Kastriot (Đerđ Kastrioti) odnosno Skenderbeg je srpskog porekla i sa Srbima je zajedno ratovao protiv Turaka. On stupa u kontakt i koordinira aktivnost sa srpskim despotom Đurđem Brankovićem u zajedničkoj borbi protiv Turaka. Borba je bila veoma teška i iscrpljujuća, i dok su balkanske države jedna za drugom definitivno potpadale pod tursku vlast (Vizantija 1453, Srpska despotija 1459, Peloponez 1460, Bosna 1460), Skenderbeg se još uvek sam i uz neznatnu pomoć sa strane, borio sa ogromnom turskom vojskom. On je gotovo neprekidno držao Kroju i još neke krajeve Albanije sve do svoje smrti 1468 godine, odloživši tako definitivno osvajanje Albanije od strane Turaka, koje je završeno padom Skadra 1479. i Drača 1501. godine. Veliki deo sadašnje Albanije je bio naseljen Srbima. Skadar je bio sedište kneza Mihajla i Bodina, osnivača prve srpske države u Duklji. Na Kosmetu nije bio Šiptara - Albanaca sem u Istiniću i nekoliko porodica u Prizrenu i Novom Brdu (Radoslav Gaćinović, Otimanje Kosova i Metohije, Novinsko-izdavački centar „Vojska“, Beograd, 2004, str. 9).
} 
turu koje je čak i stambolski sultan osuđivao, pa je bio primoran da šalje kaznene ekspedicije kako bi smirivale odmetnute šiptarske paše (Rotulli, Gjinolli, Begolli...) koje su na najgrublji način zlostavljali većinski srpski živalj na Kosmetu sa svojom privatnom vojskom. U evropskoj nauci je dobro poznato da matične oblasti albanskog naroda čine oblasti današnje srednje Albanije. Poznati nemački albanolog Štatmiler (Georg Stadtmuller) ističe da matična oblast Albanaca obuhvata dolinu reke Škumbe, obe strane reke Mat, Kroju, i još neke susedne krajeve. Istorija Albanaca i albanskog društva je veoma složena i to ne samo na prostoru današnje Albanije nego i u susednim državama u kojima Albanci žive kao nacionalne manjine. Njihova verska heterogenost i naglašen plemenski identitet bili su stalni izvori unutrašnjih međusobnih sukoba koji toj državi daju obeležje izrazite nestabilnosti. Takvo stanje mlade države ugrožava pre svega ne albanske narode u samoj Albaniji, ali u susedstvu. Ne sme se zanemariti činjenica da su vekovima na prostoru današnje Albanije postojala velika slovenska naselja i da se slovenska toponimija u priličnom broju očuvala i do početka XXI veka. U novije vreme, od stvaranja prve albanske države 1912. godine, a naročito za vreme vladavine komunističkog diktatora Envera Hodže, znatan deo nealbanskog, naročito slovenskog, stanovništva, osim Grka, bio je albanizovan najbrutalnijim sredstvima državne represije. Svedočenja stranih autora najbolja su ilustracija o etničkim, političkim i verskim prilikama u oblasti Kosova i Metohije. To su radovi Ami Buea (Ami Boué), Jozefa Milera (Joseph Miller), Hana (Johann Georg von Hahn), Ivana Stepanoviča Jastrebova, Aleksandra Giljferinga, Viktora Berara (Viktor Berrera), Gastona Gravijea (Gaston Gravier) i drugih. Jozef Miler saopštava podatke iz 1838. godine o verskoj i jezičkoj strukturi stanovništva u Metohiji - u Peći, Prizrenu i Đakovici, u Peći su Srbi imali većinu 92,09\% u odnosu na Albance. U Prizrenu je procenat Srba bio $73,68 \%$, jedino je Đakovica imala izrazitu albansku većinu i to $80,76 \% .{ }^{14}$ Kosovo i Metohija, shvaćeni kao deo Srbije omeđen granicama autonomne pokrajine, jeste prostor površine 10.887 kvadratnih kilometara, što čini 12,3 odsto teritorije Srbije. Fizičko geografske odlike Kosova i Metohije imale su karakter elemenata /delova/ „makrotvrđave“ mnogo više u vreme srednjovekovne srpske države nego na početku XXI veka, ali, zahvaljujući prvenstveno specifičnom reljefu, njihov geopolitički položaj i uloga jasno se identifikuju i u savremenim okolnostima. Istorijsko-geografske i antropogeografske činjenice takođe ukazuju na to da postojanje srpske kosovsko-metohijske „makrotvrđave“ ima racionalna uporišta. Kosovsko-metohijski prostor ${ }^{15}$ je istorijsko sedi-

\footnotetext{
14 "Velika Albanija - zamisli i moguće posledice, Zbornik radova, izd."Institut za geopolitičke studije, urednik Jovan M. Čanak, Beograd 1998. godine str. 21 i 22.

${ }^{15}$ Prirodni „mozaik“ Metohijske i veliko kosovske kotline, zajedno sa njihovim neposrednim planinskim obodom, upotpunjuje više interesantnih orohidrografskih pojava i kurioziteta: čak 12 epigenija u metohijskoj kotlini; „metohijske Plitvice" - reka Miruša (30 km), koja je u gornjem toku ponornica, a u 10 km dugačkom kanjonskoklisurskom delu doline nalazi se 13 kaskadno poređanih jezeraca i više vodopada; Mermerna pećina dugačka 1.118 metra kod Uroševca (formirana u mermeru, a ne u krečnjaku); bifurkacija Nerodimke - „veštački nastala, a prirodno predisponirana“ (prema A. Uroševiću), ili „prvobitno prirodna, a potom veštačka“ (prema J. Đ. Markoviću) pojava oticanja vode iste reke u dva morska sliva - u Sitnicu (crnomorski) i Lepenac (egejski); hidrografski čvor Srbije na Drmanskoj glavi (planina Crnoljeva); piraterija Ibra, nastala tako što je Donji Ibar probio razvođe kod Drena (između Leposavića i Leška) i preuzeo vode srednjeg i gornjeg (rožajskog) lbra, nekadašnjih pritoka neogenog kosovskog jezera. (Dr Milomir Stepić, Geografske osnove geopolitičkog položaja Kosova $i$ Metohije, U Zborniku, „Kosovo i Metohija - izazovi i odgovori“, izd. Institut za geopolitičke studije Beograd 1997. godine str. 232).
} 
šte, državotvorno jezgro i centralna teritorija srednjovekovne srpske države, a te osobine svakako spadaju u najznačajnije geopolitičke karakteristike svake države. ${ }^{16}$

Kosovo i Metohija su oduvek bili središnje oblasti srpskog naroda, a to potvrđuju najznamenitiji spomenici srpske arhitekture i srpske duhovnosti. Nameće se logično pitanje: zašto bi Srbi sedište svoje crkve - Pećke Patrijaršije podizali u oblasti u kojoj nisu u većini i koja ne bi bila sedište njihovog naroda. Srpsko istorijsko pravo nad ovim prostorima niko ne može osporiti. Međutim, šiptarski teroristički pokret je izabrao strategiju nasilja nad, od kraja devetnaestog veka većinskim Srpskim stanovništvom i tom strategijom je korak po korak skoro stigao do cilja, tj. sticanjem etničkog prava nad ovim prostorima. No, sigurno da je ustavno i istorijsko pravo Republike Srbije nad Kosmetom najdominantnije pravo. Intenziviranje Šiptarskog nasilja prema Srbima počinje nakon osnivanja Prve prizrenske lige 10 juna 1878. godine u Prizrenu. ${ }^{17} \mathrm{Na}$ ovom skupu našlo se tada oko 300 predstavnika iz svih krajeva u kojima žive Albanci i Šiptari. Na skupštini Lige u Prizrenu izabran je glavni odbor lige od 60 ljudi, na čijem čelu su se tada nalazili Abdul-beg Frašeri, Imer Prizreni (Prizrenac), mederiza glavne (bajrakli) džamije u Prizrenu i drugi. Odlučeno je da se odbori i ogranci Lige obrazuju u svim mestima u kojima žive Albanci. Nacionalni pokret i ideje o etničkom ujedinjenju Albanaca nastale su odmah posle Berlinskog kongresa, na kome je doneta odluka da se Turska mora povući sa najvećeg dela okupiranog balkanskog poluostrva. Austriji nije odgovaralo da sve te teritorije pripadnu hrišćanskim balkanskim narodima, a posebno su bili protiv teritorijalnog proširivanja Srbije i Crne Gore koje bi imale zajedničku granicu, a u vojnom smislu postale respektabilniji faktor na Balkanskom poluostrvu. Austrija je izričito zahtevala da Turski vilajeti (skadarski, kosovski, bitoljski i janjinski) i dalje ostanu u okviru Turske carevine kako bi tada Albanci dobili autonomiju i bili bi vojno usmereni protiv Srbije i Crne Gore. Takve ponude od strane Austrije, Albance su veoma ohrabrile a rodonačelnik te ideje je bila prva prizrenska liga. Prva prizrenska liga - kod Turaka poznata kao Arnaut kongra. Na čelu lige bile su braća Avdul, Naim i Sani Frašeri, inače viši činovnici na turskoj Porti. Prizrenska liga je prvenac ideje o stvaranju etnički čiste Velike Albanije. Prva prizrenska liga je tvorac ideje od stvaranju Albanske nacionalne armije (ANA) koja bi egzistirala na albanskim etničkim

\footnotetext{
${ }^{16}$ Reljef Kosova i Metohije je planinskog karaktera, sa dve veće kotline (Kosovskom i Metohijskom) čiji je reljef znatnim delom pogodan za navodnjavanje. Obe kotline obuhvataju 36,5 odsto ukupne površine, a brdskoplaninski deo obuhvata 63,5 odsto površine Pokrajine. Kosovsku kotlinu čini ravnica duž reke Sitnice, sa prosečnom nadmorskom visinom od oko 500 metara, dok je Metohijska kotlina blago talasast teren sa prosečnom nadmorskom visinom od oko 400 metara. Klima Kosova i Metohije je određena razuđenim reljefom, blizinom Jadranskog i Egejskog mora, pravcem pružanja planina i kotlina, kao i mrežom brojnih reka. Kosovska kotlina je suvlja od Metohijske kotline. Zajedničko za obe kotline je da im nedostaju letnje padavine, ali je raspored padavina povoljniji na Kosovu polju nego u Metohiji. Na osnovu padavine i temperature vazduha prostor Pokrajine bi se mogao podeliti na tri klimatska rejona: rejon umereno kontinentalne klime, rejon subplaninske klime i rejon planinske klime (Radoslav Gaćinović, Otimanje Kosova i Metohije, Novinsko-izdavački centar „Vojska“, Beograd, 2004, str. 11).

${ }^{17}$ Dokumenti Lige otkrivaju suštinu pokreta. Sednice su održavane u Prizrenskoj džamiji, a posebno obeležje Statuta (Karatname) bio je islam. U svih 16 članova Statuta nigde se izričito ne pominju Albanci i Albanija, već se sasvim uopšteno govori o „naciji i domovini“, „zemlji“, „našem kraju“, „balkanskoj zemlji“, „na Balkanu“, i sl. Politički subjekt Saveza (Lige) jednostavno su Muslimani. U članu 7. govori se o potrebi saveza s „našim mučeničkim zemljama i pripadnicima iste vjere na Balkanu" a u poslednjem članu 16 napuštanje saveza se kvalifikuje kao otpadanje „od islama“. Uostalom, tom skupu su prisustvovali i muslimanski veleposednici iz Raške, pa čak i iz Bosne i Hercegovine (Slavko Terzić, Vojska od 22.03.2001).
} 
Iskustva i pouke iz prošlosti

prostorima. Nakon formiranja Prve prizrenske lige formiraju se dalje Pećka liga, Kosovski komitet, Nacionalni front Albanaca a sve sa ciljem da se organizuju pobune i da se svaka postojeća srpska vlast diskredituje u očima međunarodne zajednice, kako bi na takvim osnovama Šiptari dobili podršku međunarodne zajednice za ostvarivanje njihovih separatističkih ideja o stvaranju etnički čiste Velike Albanije. Posle prinudnih seoba Srba 1690. godine pod patrijarhom Arsenijem Čarnojevićem pokrajinu je napustilo 40.000 Srba, zatim 1737. godine pod patrijarhom Arsenijem Jovanovićem Šakabentom proterano je 20.000 Srba, a Albanci iz svojih planinskih istočnih oblasti, koristeći privilegije turskog okupatora, zaposedaju napuštena srpska imanja i samim tim znatno menjaju etničku strukturu stanovništva u kolevci srpske državnosti i duhovnosti. Na Kosovu i Metohiji je Šiptara do tada bilo u neznatnom broju, uglavnom u planinskim predelima. Šiptarski doseljenici su bili privrženi otomanskom režimu, jer im je taj režim omogućavao privilegije nad hrišćanskom rajom.

\section{Prva prizrenska liga definisala metode nasilja Albanaca nad Srbima}

Prva prizrenska liga odmah po formiranju uz pomoć Turske i Austrije rasvetljava svoje dubinske dimenzije a to je mržnja i netrpeljivost prema Srbima. Najvažnije je bilo da srpske, grčke i crnogorske teritorije, u momentu raspada turske imperije, ne pripadnu matičnim državama, već da se viševekovna okupacija od strane Turaka proglasi za "status quo“, te da se one uključe u novostvorenu državu tkz. Veliku Albaniju, bili su glavni ciljevi Prve prizrenske lige. Nasilje nad srpskim stanovništvom od formiranja prve prizrenske lige pa do 1912. godine (kada je oslobođena Stara Srbija) bilo je više izraženo nego u proteklih stotinu godina. To se najbolje vidi iz prepiske srpskih konzula u Prištini Spalajkovića, Nušića, Rakića i drugih, kao i protesne note Kraljevine Srbije u Carigradu, gde se zahteva zaštita srpskog stanovništva od torture šiptarskih terorista. ${ }^{18} \mathrm{U}$ to vreme dnevni list Politika je o nasilju Arnauta, između ostalog pisala: „Put Mitrovica - Peć skoro je sasvim zatvoren zbog arnautskih četa. Čuje se, da se o pošti, koja je tim putem išla iz Mitrovice za Peć, ništa ne zna. U opšte je u Đakovici i okolini jako vrenje među Arnautima, koji traže šerijat i činovnike koje oni hoće. Nije bolje ni u pećkoj okolini ni u Labu, jer je tu ovih dana u okolini Vučitrna čitava dva dana trajao sukob između žandarmerije i arnautske čete." ${ }^{19} \mathrm{U}$ poslednjoj deceniji XIX veka uspostavljen je prvi konzulat Kraljevine Srbije u Prištini u cilju izgrađivanja međudržavnih odnosa između Srbije i Turske. Prvi konzul je bio Luka Marinković, koga su vrlo brzo ubili šiptarski teroristi u Prištini zbog toga što je redovno izveštavao svoju vladu o zločinima Šiptara nad srpskim stanovništvom na Kosovu i Metohiji. ${ }^{20}$ Pored konzula Šiptari su likvidirali veliki broj uglednih Srba na Kosmetu, pored likvidacija, vršili su otmice, a nakon toga su otete Srbe mučili do smrti, a veoma je bio izražen trend silovanja srpskih žena i devojaka. Pored ovih zločina bilo je i drugih kao npr. paljenje kuća, skrnavljenje i pljačkanje crkava i bogomolja, premlaćivanje ljudi iz čiste obesti, otimanje stoke, teranje Srba na kulučenje i besplatne radove - naročito ne-

\footnotetext{
${ }^{18}$ Rajko Vidačić, „O korenima separatizma i terorizma na Kosovu“izd. Službeni list SRJ, Bgd. 2000, str. 7 do 23.

${ }^{19}$ Politika, 14. april 1912.

${ }^{20}$ Rajko Vidačić, „O korenima separatizma i terorizma na Kosovu“ izd. Službeni list SRJ, Bgd. 2000, str. 15.
} 
deljom i za vreme pravoslavnih praznika. Turske vlasti su to sve prećutno odobravale i time bile lično uključene u sprovođenje nasilja nad nezaštićenim srpskim stanovništvom. Jedina institucija koja je okupljala Srbe na Kosovu i Metohiji bila je Bogoslovija, osnovana 1870. godine u Prizrenu zaslugom Sime Andrejevića Igumanova, trgovca iz Prizrena. Do 1912. godine Bogosloviju je završilo 480 učenika od toga 200 sa Kosova i Metohije. ${ }^{21}$ Posle Prvog balkanskog rata 1912. godine, u kome su Albanci bili na strani Turske, Konferencija ambasadora u Londonu 1913. godine utvrdila je granice novoosnovane albanske države. Albanci su dakle voljom velikih sila, dobili državu čijim granicama nisu bili zadovoljni, jer su bile znatno manje od vilajetskih okvira na koje su se pozivali albanski predstavnici prilikom proglašavanja nezavisne Albanije na skupu u Valoni 28. novembra 1912. godine. To nezadovoljstvo su izrazili u Memorandumu upućenom Konferenciji 2. januara 1913. godine tražeći da se albanske granice prošire i da u sastav Albanije uđu gradovi Peć, Mitrovica, Priština, Skoplje i Tetovo sa njihovom okolinom. Na tim nerealnim zahtevima uporno su se angažovali Albanci i njihova udruženja širom sveta. Bila su veoma aktivna albanska udruženja u Evropi a posebno albansko društvo „Vatra“ u SAD-u, u vezi sa proširivanjem albanskih granica. Šiptarski teroristi su svoje nezadovoljstvo ispoljavali nasumičnom primenom nasilja prema Srbima, posebno prema sveštenicima Srpske Pravoslavne crkve na Kosovu i Metohiji. ${ }^{22}$

Talas velikih nacionalnih pokreta hrišćana na Balkanskom poluostrvu, započet 1804, srpskom revolucijom predodredio je, u većoj meri nego u prethodnim stolećima, sudbinu srpskog naroda, a Arbanase (oko $70 \%$ muslimanske vere) učinio najvažnijim čuvarima turskog poretka u evropskim pokrajinama Osmanskog carstva. U uslovima ponovnog otvaranja istočnog pitanja, posebno u poslednjoj četvrtini XIX i u prvoj deceniji XX veka, islamski Arbanasi bili su glavno oruđe turske politike u suzbijanju oslobodilačkih pokreta susednih naroda i moćno sredstvo izolacije oslobođenih država. ${ }^{23}$

Posle Berlinskog kongresa, buknuo je arbanaški nacionalni pokret koji su, s nejednakim uspehom, pokušavali da instrumentalizuju i Visoka Porta i Austrougarska, sila koja je okupacijom Bosne i Hercegovine (1878) najavila svoju dalju ekspanziju u dubinu Balkana. Dok je Porta Arbanase koristila kao udarnu oštricu islama protiv hrišćana u pograničnim krajevima prema Srbiji i Crnoj Gori, pre svega na Kosovu, u Metohiji i Makedoniji,

${ }^{21}$ Dušan Bataković, Kosovo i Metohija: Istorijsko nasleđe i geopolitička ograničenja, u Zborniku radova „Kosovo i Metohija izazovi i odgovori“, izd. Institut za geopolitičke studije Beograd 1997. godine, str. 366-367.

${ }^{22}$ U toku 1915-1918. godine na Kosovu i Metohiji su od strane šiptarskih terorista ubijeni srpski jerarsi i sveštenici: Mitropolit Vićentije i njegov đakon Cvetko Nešić, koji su 23. novembra 1915. godine odvedeni iz Prizrena noću za Uroševac, gde su 25. novembra vezani žicom za bandere i poliveni gasom živi spaljeni; Jeromonah Danilo, starešina manastira Svetog Marka Koriškog, zaklan od strane arnauta 17. novembra 1917. god. sa još šest sveštenika; Jeromonah Sava Popović iz manastira Gračanica ubijen je noću 16. aprila 1916. godine od strane Šiptara u svojoj kući u Prilužju; Iguman Rufin Nikolić, starešina manastira Devič, otrovan 1917. godine; Prota Kosta Jovanović iz Prizrena ubijen decembra 1915. godine; Ljubomir Repić, paroh Prizrenski, mučen i podlegao mukama 17. novembra 1917. godine; Srećko Đurić, paroh Pećki, ubijen 1917. godine; Sveštenik Dena Debeljaković, paroh Lipljanski, zaklan 12. novembra 1915. godine; Sveštenik Miljko Simić, iz Suhog Grla u Metohiji, ubijen novembra 1915. godine; Vićentije Simić, paroh Sočanički, obešen sa još 12 viđenijih Srba iz Sočanice u K. Mitrovici 30. januara 1917. godine; Đura Stojanović, paroh Zočiški, ubijen 20. aprila 1918. godine između Zočišta i Retimlja; Prota Novopazarski Toma Protić i njegov saparoh Kosta Kulagić iz Novog Pazara 9.11.1915. godine; Petar Bačanin, paroh Vračevski ubijen 28.9.1915; Petar Popović, paroh Štavički kod Rožaja ubijen sa dva Srbina blizu Sopoćana 10.11.1915. godine. (Memorandum o Kosovu i Metohiji Svetog Arhijerejskog sabora Srpske Pravoslavne crkve, Beograd, 2003. godine, str. 37- 38.

${ }^{23}$ Dušan T. Bataković, Kosovo i Metohija u srpsko-albanskim odnosima, Čigoja, Beograd, 2006, str. 36. 
Iskustva i pouke iz prošlosti

Austrougarska je nastojala da tek razbuđen arbanaški nacionalni pokret okrene protiv dveju srpskih država, koje su bile prepreka germanskom prodoru na istok. Premda nezavisne od 1878. Srbija i Crna Gora, bez podrške Rusije ili neke druge velike sile, bile su sve do Balkanskih ratova nemoćne da osetnije utiču na sudbinu svojih sunarodnika unutar granica Osmanskog carstva. ${ }^{24}$

\section{Kontinuirano proterivanje Srba sa Kosova i Metohije}

Zaplašeni obnovom srpske države, kosovske paše su nastojale da nemilosrdnim progonima umanje broj Srba na svojim prostornim posedima. Francuski putopisac F. Pukvilj (Fr. Pouqueville) bio je zaprepašćen razmerama bezvlašća i ostrašćenošću lokalnih paša prema hrišćanima: Jašar-paša Džinić iz Prištine je rušio crkve, oduzimao manastirske zemlje i ubijao kaluđere, za nekoliko godina raselio je, smatra se, preko sedamdeset srpskih sela na prostoru između Vučitrna i Gnjilana, a njihova imanja razdelio domaćem islamizovanom življu i gorštacima doseljenim iz severne Albanije. Plodne ravnice Kosova ubrzo su postale zapuštene utrine koje hrabri malisorski brđani, stočari i nomadi, nesvikli na zemljoradnju, nisu umeli da obrađuju. ${ }^{25}$

Svedočanstva o razmerama nasilja na Kosovu i Metohiji, od ucena i pljački do silovanja i ubistava, donosi i niz sadržajnih stranih putopisa, od A. F. Giljferdinga do Mjur Mekenzijeve i Irbijeve. ${ }^{26}$ Ruski konzul u Prizrenu zapazio je da se Arbanasi muslimani nesmetano naseljavaju u Prizrenskom Sandžaku, a da Turci nastoje da s Kosova i Metohije nestane Srba hrišćana. Svaki odmetnik (kačak), ako je musliman, mogao je da hrišćanina napadne, opljačka, a ako ovaj pokuša da se odupre, da ubije, bez straha da će za to odgovarati. Raja nije imala pravo da nosi oružje: oni malobrojni Srbi koji su ga imali i upotrebili u samoodbrani morali su da beže u druga područja. Samo naj spretniji među njima uspevali su da se domognu srpske ili crnogorske granice i da tamo nađu trajno utočište. Za njima su, po pravilu, dolazile i mnogočlane porodice (živelo se u porodičnim zadrugama koje su dostizale i do 30 duša) jer nisu mogle da se odbrane od osvetnika mnogobrojnih srodnika Arbanasa stradalih u sukobu sa starešinom njihove zadruge. Ekonomski pritisak, naročito nasilno prevođenje slobodnih seljaka u kmetove (čifčije), sprovodili su arbanaški feudalci kako bi stvorili velika i zaokružena vlastelinstva. ${ }^{27}$

\footnotetext{
${ }^{24}$ Isto, str. 39.

${ }^{25}$ F. C. H. I. Pouqueville, Voyage dans la Gréce, II, Paris 1820- 474-487; Vladimir Stojančević, Južnoslovenski narodi u Osmanskom Carstvu od Jedrenskog mira 1829. do Pariskog kongresa 1856. godine, Beograd 1971.

${ }^{26}$ Putovanje po slovenskim zemljama Turske u Evropi od g-đica G. Mjur Makenzijeve i A. P. Irbijeve, Beograd 1868; Aleksandar F. Giljferding, Putovanje po Hercegovini, Bosni i Staroj Srbiji, Sarajevo, 1972.

${ }^{27}$ Preduzimljive srpske trgovce i zanatlije, koji su u Prištini, Peći i Prizrenu uspešno razvijali poslove, turske vlasti nastojale su da ograniče, a u ratnoj pometnji $(1859,1863)$ spaljivane su čitave četvrti u kojima su poslovali i imali radnje. Na selu je, ipak, bilo najteže, jer su Abranasi, udruženi u čvrste zajednice krvnog bratstva ili u plemena, socijalno relativno homogeni, terorisanjem Srba, otimanjem njihovih imanja i stoke, bez mnogo napora dolazili do dobara kojima su izdržavali svoje srodnike i saplemenike. Potiskivanjem srpskog seljaštva stvarali su slobodan prostor za doseljavanje svojih srodnika iz severne Albanije, čime je rastao i njihov ugled među drugim plemenima. Nesvikli na život u ravnici i težak rad u polju, doseljeni Arbanasi su se radije bavili pljačkom nego zemljoradnjom (Dušan T. Bataković, „Od srpske revolucije do istočne krize 1804-1878“, 186-190, 204-208.; Đ. Mikić, Društvene i ekonomske prilike kosovskih Srba u XIX i početkom XX veka. Od čif̌ijstva do bankarstva. SANU, Posebna izdanja, knj. DLXXXVIII, Beograd 1988).
} 
Uprkos svim teškoćama, srpski narod na Kosovu i Metohiji okupljao se u crkveno-školske opštine koje su finansirale otvaranje škola i obrazovanje dece. Položaj srpskog stanovništva u gradovima bio je, izuzev u razdobljima kriza, znatno povoljniji nego onih u seoskim područjima. Osim manastirskih, od sredine tridesetih godina XIX veka otvorene su i prve srpske svetovne škole na Kosovu, a 1871, trudom dobrotvora S. A. Igumanova, i Bogoslovija u Prizrenu. Kneževima Srbija, nemoćna da politički osetnije pomogne, još od četrdesetih godina XIX veka sistematski je novcem i drugim prilozima pomagala crkve i škole, upućivala i plaćala učitelje za škole, a najbolje đake slala na studije u Srbiju. U prizrenskoj Bogosloviji, središtu rada na narodnim poslovima, školovali su se učitelji i sveštenici za sve srpske zemlje pod turskom vlašću, a krišom od turskih vlasti uspostavljena je i redovna veza s vladom u Beogradu, od koje su dobijana i sredstva i uputstva za političko delovanje. ${ }^{28}$

Uoči kongresa u Berlinu u leto 1878, na periferiji arbanaškog etničkog prostora, u Prizrenu, formirana je Arbanaška liga: njeno vođstvo zahtevalo je očuvanje celokupnosti Osmanskog carstva u granicama pre ratova i stvaranje autonomne arbanaške jedinice od Kosovskog, Skadarskog, Janjinskog i Bitoljskog vilajeta, oblasti gde su Arbanasi činili 44\% ukupnog stanovništva. Teritorijalne pretenzije arbanaškog pokreta fiksirane 1878. ušle su u osnove svih potonjih nacionalnih programa. Proosmanski i proislamski karakter Lige podržao je i novi sultan Abdulhamid II (1876-1909). Napustivši reformatorsku politiku svojih prethodnika, on je za načelo svoje vladavine uzeo panislamizam. Nezadovoljna odlukama Berlinskog kongresa, Liga se oružjem usprotivila ustupanju Plava i Gusinja Crnoj Gori, a njeni odredi počinili su nebrojena nasilja nad Srbima, koji su smatrani trajnom opasnošću po arbinaške nacionalne interese. Truska je 1881. silom slomila Ligu, čije je radikalno krilo težilo stvaranju nezavisne države, kako bi pred Evropom pokazala da je sposobna da sprovede prihvaćene reforme. Uprkos tome, Arbanasi su, u sistemu turske uprave na Balkanu i u sledećim decenijama zauzimali najistaknutije mesto. ${ }^{29}$ Verska i etnička netrpeljivost Arbanasa prema Srbima dobila je nov, politički sadržaj: strateški cilj arbanaške nacionalne politike bio je sistematsko istiskivanje Srba iz ovih krajeva. Politika sultana da lancem arbanaških naselja obezbedi novu granicu prema Srbiji, a da Arbanasi kao zatočenici islama nesmetano suzbijaju sve nemire Srba i drugih hrišćana u evropskim pokrajinama Carstva učinili su od Kosova i Metohije krvavo razbojište, gde su stradanja srpskog stanovništva dobila zabrinjavajuće razmere. Od 1876. do 1883. pred arbanaškim zulumima u Srbiju je sa Kosova i Metohije izbeglo oko 1.500 srpskih porodica. ${ }^{30}$

Razdoblje reformske akcije Srbima na Kosovu i Metohiji i susednim krajevima nije značilo nikakvo poboljšanje uslova života, a nije im donelo ni željene garancije lične i imovinske sigurnosti. ${ }^{31}$ Jedan američki putopisac je na početku reformske akcije zapazio da su turske vlasti u Staroj Srbiji obezbedile lojalnost Gega, i hrišćana i muslimana, dozvoljavajući im „da progone i ubijaju svoje susede nearbanaškog porekla koliko im

\footnotetext{
${ }^{28}$ J. K. Đilas, Srpske škole na Kosovu od 1856. do 1912. Studija zajedničkih naučnih ustanova Kosova i Metohije, Priština 1969.

${ }^{29}$ Bernard Stulli, „Albansko pitanje“, Rad JAZU, 316. Zagreb, 1959, 287-391, Dimitrije Bogdanović, Knjiga o Kosovu, Posebna izdanja, SANU, DLXVI, Beograd, 1985, str. 142-148.

${ }^{30}$ Vladimir Boban, Jastrebov u Prizrenu, Jedinstvo, Priština 1983, str. 180-185.

${ }^{31}$ Iz jednog privatnog pisma Dimitrija Popovića, načelnika Ministarstva inostranih dela, od 2/15. juna 1905, vidi se da je bilo planirano da se prikupi „što veći materijal o nevoljama i patnjama kojima je srpski element u kosovskom vilajetu izložen. Taj bi materijal poslužio za eventualan korak kod velikih sila“. (ASANU, br. 14243/4565).
} 
duša hoće. Oni stalno dalje pritiskaju, paleći, pljačkajući i ubijajući Srbe u kosovskom vilajetu. Granična linija Albanije se proširila sve do Stare Srbije. Čak ni granica Srbije ne znači ništa tim brđanima odanim bezakonju. Ona često vrše upade u susednu državu, kao što su činili u Bugarskoj, kad su kao vojnici bili na toj granici“. ${ }^{32}$ Jedan drugi svedok, britanski novinar H. N. Brejlsford (Henry N. Brailsford) je, obilazeći Staru Srbiju 1905, bio zapanjen teškim položajem Srba u Metohiji: „Danas su Srbi ostatak koji se zbog emigracije, masakra i nasilne konverzije, smanjio na jedva trećinu stanovništva: u dva distrikta Prizrena i Peći nema više od 5.000 srpskih kuća nasuprot 20 ili čak 25.000 arbanaških porodica. Od ostatka srpske hrišćanske populacije u Staroj Srbiji, svaki deseti je tokom poslednjih godina u beznađu prebegao u slobodnu Srbiju. Preostali, nenaoružani i nezaštićeni, preživljavaju samo zato što su ušli u naročitu vrstu feudalnog odnosa sa nekim arbanaškim silnikom. Arbanas se eufemistički naziva njihovim 'zaštitnikom'. On živi u snošljivim odnosima sa svojim srpskim vazalom. On je obično spreman da ga brani od drugih Arbanasa, a zauzvrat ga beskrajno ucenjuje na najrazličitije načine. ${ }^{33} \mathrm{Na}$ pitanja kako funkcioniše vlasništvo nad zemljom Brejlsfordu je odgovarano samo osmehom: „Sistem zakupa zemlje u ovoj državi, gde su Kuran i puška jedini zakon, ono je što arbanaški poglavica oblasti odluči da bude. Srpski seljaci, vezani za zemlju, su zakupci zavisni od volje svakog kaprica njihovih domaćih porobljivača. Iz godine u godinu arbanaški brđani nadiru u ravnicu, a srpski seljaci se povlače pred njima. ${ }^{34}$

Stara strahovanja od aspiracija Srbije, što su pothranjivali agenti bečke diplomatije, znatno su doprinela razmerama nasilja. Već sama pojava, u dva navrata, srpskih četnika, koji su na putu ka Makedoniji otkriveni na Kosovu i Metohiji (u Velikoj Hoči 1905. i Pasjanu 1907), izazivala je pravu konsternaciju među Arbanasima, koja je pretila da se pretvori u pokretu za opšti pokolj srpskog stanovništva, osumnjičenog za saučesništvo sa pohvatanim četnicima. ${ }^{35}$ Opšta politička situacija nije pogodovala pokušajima internacionalizacije kosovskog pitanja, ali su pojedina patriotska društva u Srbiji, s nejednakim uspehom, nastojala da brošurama na stranim jezicima evropskoj javnosti predstave razmere stradanja srpskog življa u Staroj Srbiji i Makedoniji. ${ }^{36}$ Prve godine mladoturske vladavine nisu Srbima donele obnarodovanu jednakost, a ni očekivano olakšanje. Posle početnog zadovoljstva mogućnošću da se politički legalizuju, obrazuju svoju nacionalnu stranku i istaknu kandidate za mladoturski parlament, Srbi su se iznova, u izvesnoj meri i dramatičnije nego ranije, našli u procepu između Arbasa, i dalje dominirajuće snage u Staroj Srbiji, i turskih vlasti koje su sve manje uspevale da održavaju proklamovani poredak. Arbanasi su, stalno se sukobljavajući s mladoturcima, ogorčeni pokušajima vlasti da ograniče njihovo ne pokoravanje propisanim zakonima, stali da s novom energijom nasrću na i dalje nezaštićen srpski živalj. Najteža situacija bila je u oblasti Peći: tamošnjim Srbima Arbanasi su stavljali do znanja da proglašenje ustavnosti smatraju samo privre-

\footnotetext{
${ }^{32}$ Ferdinand Moore, The Balkan Trail, New York 1906 (reprint 1971) 223.

${ }^{33}$ Henry N. Brailsford, Macedonia Ils Races and Their Future, London 1906, 274-275.

${ }^{34}$ Isto, str. 276.

${ }^{35}$ Milan Rakić, Konzulska pisma 1905-1911(prir. A. Mitrović), Prosveta, Beograd, 1985, str. 41-46, 131-136.

${ }^{36}$ Mémorandum sur la situation des Serbes en Macédonie et en Vielle Serbie, „Srpske braće" Belgrade 1907, str. 15.
} 
menom merom i da se nikada neće pomiriti s mogućnošću da đauri (nevernici) steknu ista prava kao muslimani. ${ }^{37}$ Izveštaji srpskih konzula i njihovih poverenika iz ovog razdoblja ukazuju na znatan porast nasilja u svim krajevima Stare Srbije. Broj prebeglih na srpsku teritoriju nije se smanjivao već je pokazivao tendenciju osetnog rasta.

Prema nepotpunim podacima srpskih pograničnih vlasti, tokom 1907. iz Kosovskog vilajeta je samo u Toplički okrug prebeglo i tamo se privremeno nastanilo oko 200 duša, među kojima se, osim Srba, našlo i nekoliko vojnih begunaca, što Arbanasa što Srba muslimanske vere. Samo u prvoj polovini 1908. u Kosanički i Prokupački srez je iz Stare Srbije prebeglo 61 lice, od kojih je sedmoro povelo još 24 člana uže porodice-žena i dece. U istom razdoblju u Vranjskom okrugu utočište je našlo 28 starešina srpskih zadruga sa 110 članova porodica, dok je, prema spisku sačinjenom sredinom oktobra 1908. u Niškoj eparhiji, iz Stare Srbije i susednih krajeva u Srbiju pred arbanaškim nasiljem izbeglo ukupno 40 sveštenih lica.

Svi pokušaji zvanične Srbije da se plemenskim vođama i uticajnim glavarima na Kosovu i Metohiji postigne sporazum nisu urodili plodom, a mnogi planovi pali su u vodu jer se među Arbanasima nisu mogli naći pouzdani ljudi koji bi se držali dogovora. Zbog toga je, početkom 1908. godine srpska vlada pokušavala da izdejstvuje da se u Peći, središtu Metohije, otvori ruski ili britanski konzulat kako bi se pariralo Austrougarskoj propagandi: krajnji cilj, ovih nastojanja bio je da se i Metohija i Kosovo, posle otvaranja jednog od konzulata velikih sila, uključe u reformsku akciju.

Sve do kraja osamdesetih godina XIX veka Srbima na Kosovu i Metohiji jedinu zaštitu pružali su diplomatski predstavnici Rusije, tradicionalne zaštitnice pravoslavnog i slovenskog življa u Turskoj carevini. Slabljenje ruskog uticaja na Balkanu posle Berlinskog kongresa nepovoljno je uticalo na ukupan položaj Srba u evropskoj Turskoj. Zbog austrofilske politike Milana i Aleksandra Obrenovića, Srbija je izgubila podršku Rusije na Porti, posebno u diplomatskim akcijama oko zaštite srpskog stanovništva. Na Kosovu i Metohiji na Srbe se, u osmanskoj administraciji, gledalo kao na prevratnički, veleizdajnički elemenat, pa se svaki njihov pokret pažljivo pratio, a nagoveštaji pobune nemilosrdno kažnjavali. U Prištini je 1882. osnovan preki vojni sud, koji je za pet godina rada u tamnice oterao nekoliko stotina narodnih prvaka. Plimu nasilja nisu mogli da zaustave ni uporni pokušaji srpskih zvaničnika da sa arbanaškim plemenskim glavarima u Metohiji i na Kosovu utvrde sporazum i tako utiču na obuzdavanje anarhije. ${ }^{39}$

Prave razmere stradanja mogli su da sagledaju u Beogradu tek pošto je 1889. otvoren srpski konzulat u Prištini. Vlada je upozorena da Arbanasi sistematski napadaju pojedina srpska sela i da ih pretnjama i ubistvima podstiču na raseljavanje: „Hajte u Srbiju ovde za vas nema opstanka“. Ubistvo prvog srpskog konzula, Luke Marinkovića, na ulicama Prištine, pokazalo je svu dubinu arbanaške netrpeljivosti. Sve do 1905. nijedan diplomatski predstavnik Srbije u Prištini nije mogao da poseti Peć i obiđe Metohiju, žarište anarhije. Prištinski vicekonzuli i konzuli (među njima i Branislav Nušić i Milan Rakić), osim izveštaja, pisali su, za širu publiku, i posebna etnografska i putopisna dela koja su sadržavala detaljne opise stanja na Kosovu i Metohiji. Jedini diplomatski uspeh Srbije bio

\footnotetext{
${ }^{37}$ Dušan t. Bataković, Kosovo i Metohija u srpsko-arbanaškim odnosima, Čigoja, Beograd, 2006, str. 181

${ }^{38}$ Isto, str. 182,

${ }^{39}$ Dušan T. Bataković, Kosovo i Metohija u srpsko-albanskim odnosima, Čigoja, Beograd, 2006, str. 41,
} 
je izbor srpskog kandidata za raško-prizrenskog mitropolita 1896, posle niza Srbima nenaklonjenih grčkih vladara koji su od 1830 . stolovali u Prizrenu. ${ }^{40}$

Otvoreni teror počeo je posle grčko-turskog rata 1897, kad je izgledalo da će Srbe snaći sudbina Jermena Maloj Aziji, koje su s blagoslovom sultana uspešno zatirali Kurdi. Srpska diplomatija je na Porti, zalaganjem Stojana Novakovića, pokrenula akciju za zaštitu svojih sunarodnika, podnela opsežnu dokumentaciju o oko četiri stotine primera teških zločina: ubistava, ucena, pljački, silovanja, otimanja imanja, paljenja crkava. Zahtevano je da se preduzmu energične mere protiv nasilnika i da istragu sprovede mešovita srpsko-turska komisija. Cela akcija, međutim, bez konkretne podrške Rusije, nije donela nikakav rezultat. Predsednik srpske vlade, Vladan Đorđević, rezignirano je zaključio da je od 1890. do 1899. s Kosova i Metohije u Srbiju prebeglo oko 60.000 duša. U Beogradu je za potrebe Mirovne konferencije u Hagu 1899. bila odštampana „plava knjiga“ diplomatske prepiske o arbanaškim nasiljima u Staroj Srbiji, ali je Austrougarska, koristeći svoj uticaj na dvoru Obrenovića, sprečila srpsku diplomatiju da ovo pitanje iznese pred međunarodnu javnost. Sledećih godina srpska vlada je pokušala da tajno doturi oružje Srbima na severnom Kosovu. Već prvi tovari pušaka bili su otkriveni, pa je 1901. usledio novi progon u lbarskom Kolašinu, koji je obustavljen tek na intervenciju ruske diplomatije. ${ }^{41}$

Intenzitet anarhije dostigao je kritičnu tačku 1902. kada je, uz podršku crnogorske diplomatije, srpska vlada ponovo pokrenula pitanje zaštite srpskog naroda u Turskoj, zahtevajući da se zakon primenjuje jednako na sve podanike Carstva, da se prekine s politikom povlađivanja Arbanasima, da se oni razoružaju i da se pojačaju turski garnizoni u oblastima s mešovitim srpsko-arbanaškim življem. Rusija, a potom i Francuska, podržale su srpske zahteve. Dve najzainteresovanije sile, Austrougarska i Rusija, imale su od 1897. sporazum da se na Balkanu održi status kvo, ali su podstakle reformski plan za preuređenje evropskih pokrajina Turske. Uplašeni za svoje povlastice, Arbanasi su 1903. podigli veliki ustanak koji je počeo novim vrstama nasilja, a završio se ubistvom tek pristiglog ruskog konzula u Mitrovici, Grigori Stepanovič Ščerbine, srpskog zaštitnika. ${ }^{42}$

Povratak dinastije Karađorđević na presto Srbije (1903) označio je napuštanje austrofilske politike i postepeno okretanje prema Rusiji. Austrougarska je, zbog toga, pojačala propagandni rad među Arbanasima. Iz reformske akcije velikih sila (1903-1908), na zahtev Dvojne monarhije, bili su, zarad zaštite arbanaške prevlasti, izuzeti severni delovi Kosova i Metohija. Usledili su, zatim, novi talasi progona: samo sa užeg Kosova 1904. je u Srbiju prebeglo 108 lica. Od 136 slučajeva različitih nasilja, 46 se završilo ubistvom, a grupa Arbanasa silovala je i jednu sedmogodišnju devojčicu. Tokom 1905. u 281 slučaju nasilja zabeleženo je 65 ubistava, a samo na jednoj svadbi Arbanasi su ubili devet svatova.

\footnotetext{
${ }^{40}$ Od više hiljada izveštaja srpskog konzulata u Prištini do sada je objavljen samo jedan deo u izboru B. Peruničića: Pisma srpskih konzula iz Prištine 1890-1900, Beograd, 1985; Svedočanstvo o Kosovu, Beograd 1988; Zulumi aga i begova u kosovskom vilajetu, Beograd 1989. Deo značajne dokumentacije o nasilju Arbanasa nad Srbima objavljen je i u: Zadužbine Kosova 607-723, dok je Andrej Mitrović priredio vrednu zbirku diplomatskih izveštaja Milana Rakića (Konzulska pisma 1905-1911, Beograd 1985).

${ }^{41}$ Documents diplomatiques. Correspondnce concernant les astes de violence et de brigandage des Albanais dans la Vieille Serbie (Vilayet du Kosovo) 1898-1899, Belgrade, Ministére des Affaires Etrangéres MDCCCXCIX; Mihailo Vojvodić, Srbija u međunarodnim odnosima krajem XIX i početkom XX veka, SANU, Beograd 1988; Đorđe Mikić, Austro-Ugarska i mladoturci 1908-1912, Institut za istoriju, Banja Luka 1983, str. 237-238.

${ }^{42}$ Dušan T. Bataković, Kosovo i Metohija u srpsko -albanskim odnosima, Čigoja, Beograd, 2006, str. 45.

${ }^{43}$ Popisi nasilja u: Zadužbine Kosova, 672-697. O nasilju Arbanasa nad Srbima svedoče i savremeni francuski putopisi: Dušan T. Bataković, „Les Français et la Vieille Serbie“, Rapports franco-yougoslaves, Belgrade 1990, 138-150.
} 
Mladoturska revolucija 1908. kojom je okončana „epoha zuluma“, kako se u turskoj istoriografiji naziva doba vladavine Abdulhamida II, nije donela osetniju promenu u srpsko-arbanaškim odnosima. Pod okriljem mladoturskog režima stvorena je prva tamošnja srpska politička organizacija. Međutim, arbanaške pobune protiv panturske politike nove vlasti izazvale su novu plimu nasilja. Samo u drugoj polovini 1911. u Staroj Srbiji je zabeleženo $128 \mathrm{krađa,}$ 35 paljevina, 41 razbojništvo, 53 otimačine, 30 ucena, 19 zastrašivanja, 35 ubistava, 37 pokušaja ubistva, 58 oružanih napada na imovinu, 27 primera tuče i zlostavljanje, 13 pokušaja turčenja i 18 primera nanošenja teških telesnih povreda. Sa šireg prostora Stare Srbije pred arbanaškim i turskim nasiljem u Srbiju je izbeglo oko 400.000 ljudi, a samo s Kosova i Metohije oko 150.000 ljudi, tj. trećina ukupnog srpskog stanovništva na ovim prostorima. Uprkos progonima i neprestanom iseljavanju, na Kosovu i Metohiji Srbi su 1912. još činili bezmalo polovinu ukupnog stanovništva. Prema istraživanjima Jovana Cvijića objavljenim 1911, na Kosovu je bilo 14.048 srpskih kuća, u Peći i okolini 3.826, a u prizrenskom kraju 2.400 srpskih domova sa oko 200.000 stanovnika. Kad se uporede statistike iz sredine stoleća kada je na Kosovu, u Metohiji i obližnjim područjima živelo oko 400.000 Srba, onda su Cvijićeve procene da je u Srbiju do 1912. prebeglo oko 150.000 Srba sasvim uverljive i prihvatljive. ${ }^{44}$

Posle proboja Solunskog fronta u jesen 1918, savezničke trupe, uključujući i srpske jedinice, pod komandom generala Franše D’Esperea (Louis Félix Marie François Franchet d’Esperey) oslobodile su, uz sadejstvo komita Koste Pećanca, Kosovo i Metohiju i zatim ih predale na upravu srpskim vlastima. Bilo je, još pred oslobođenje, povremenih pobuna stanovništva, ali su one postale učestalije naročito posle osnivanja tzv. „Kosovskog komiteta“ u Albaniji, koji je pozivao u borbu za stvaranje „Velike Albanije“. Srpske trupe odgovorile su na albanske pretnje okupacijom pograničnih albanskih srezova i nastojale da na vlast dovedu Esad-pašu Toptanija koji je boravio u savezničkom taboru u Atini. Italija, koja je posle razbijanja Austrougarske preuzela ulogu protektora Albanije, postala je glavni suparnik tek proglašene jugoslovenske države, zbog spora oko prevlasti u Jadranskom primorju. Uspostavila je marionetski režim u Albaniji, podsticala njegove pretenzije na Kosovo, Metohiju i severozapadnu Makedoniju, nastojeći da od Albanije stvori uporište za dalje širenje italijanskog uticaja u unutrašnjost Balkana. ${ }^{45}$

Jugoslovenska delegacija na Konferenciji mira u Parizu zastupala je stanovište da bi Albanija trebalo da bude nezavisna država u granicama iz 1913. ali je, u slučaju njene podele, tražila teritorijalne kompenzacije od Drima do Skadra. Posledice svakodnevnog, nekažnjenog terorisanja hrišćana najteže su pogađale Srbe na Kosovu, Metohiji i u susednim krajevima Stare Srbije, odakle se samo u razdoblju od 1890. godine, povlačeći se ped nasiljem albanskih odmetnika u susednu Kraljevinu Srbiju, prema okvirnim procenama, iselilo najmanje 60.000 lica, tj. oko četvrtina ukupnog srpskog stanovništva u Staroj Srbiji. Brojni pokušaji srpske diplomatije da zaštiti ugrožena prava svojih sunarodnika u Osmanskom carstvu (1898-1899, 1903), bez snažne podrške velikih sila, ostajali su bez odjeka i praktičnih rezultata. ${ }^{46}$

\footnotetext{
${ }^{44}$ Jovan Cvijić, Balkanski rat i Srbija, Beograd 1912; J. Dedijer, „Stara Srbija, geografska i etnografska slika“, Srpski književni glasnik, XXX (1912), 674-699.

${ }^{45}$ Dušan T. Bataković, Kosovo i Metohija u srpsko-albanskim odnosima, Čigoja, Beograd, 2006, str. 49.

${ }^{46}$ Documents diplomatiques Correspondance concernant les actes de violence et de brigandage des Albanais ddans la Vielle Serbie (Vilayet de Kosovo) 1898/1899, Belgrade, Ministére des Affaires Etrangéres, MDCCCXCIX, pp. 1/145.
} 
Verska netrpeljivost prema Srbima, pomešana sa izvesnim rasnim predrasudama, davala je nacionalnom sukobu Srba i etničkih Albanaca posebnu snagu. Američki istoričar albanskog porekla, Stavro Skendi (Stavro Skëndi), analizirajući dubinske uzroke srpsko-albanskog sukoba, naglasio je sledeće: „Albanci na Kosovu, većinom muslimani, verski su se poistovetili sa Turcima, i na toj osnovi i sa (osmanskim) carstvom. Hrišćane, kao neprijatelje Turske, oni su zato smatrali svojim prirodnim neprijateljima. Međutim, prema Slovenima, mržnja kosovskih Albanaca nije bila zasnovana na religiji - premda ju je religija snažila - nego na etničkoj razlici: borili su se protiv „stranaca“ (Shkje - pogrdno ime za Slovene) koji su žudeli za njihovom zemljom."

U takvim okolnostima, zaštitu Srba preuzimali su ruski, a podršku Albancima davali austrougarski konzuli. Svaki nagoveštaj sistematske zaštite prava Srba hrišćana izazivao je masovne oružane akcije Albanaca: u jednoj od njih poginuo je ruski konzul G. Ščerbina, u Mitrovici 1903. godine. Nasuprot ruskim namerama da u reformi velikih sila (19031908) dobije nadzor nad Kosovom, na inicijativu Beča, severozapadni deo Kosovskog vilajeta (deo Raške oblasti, Kosovo s Metohijom) bio je 1904. godine isključen iz programa reformi, što je imalo za posledicu novi talas nasilja nad Srbima. Potiskivanjem i sistematskim progonima trebalo je da se njihov broj toliko smanji da nestane demografska osnova za srpske i crnogorske pretenzije na Kosovo i Metohiju. Srpska skupština često je raspravljala o teškom položaju Srba u Turskoj: u jednoj raspravi tokom 1908. godine konstatovano je da „pada u oči velika razlika u ponašanju Albanaca u Staroj Srbiji - na klasičnom srpskom zemljištu i u Albaniji - njihovoj kolevci. Albanci su na svom ognjištu miran, trezven, radan narod, na srpskom divljački zulumćari." ${ }^{48}$

Tražeći izlaz na more da bi se spasle gvozdenog zagrljaja Austrougarske koji se stezao, srpske trupe ušle su u severnoalbanske luke, ali su odlukama Konferencije ambasadora u Londonu (1912-1913) bile primorane da se povuku iz Albanije. Austrougarska je pokušavala da kao protivtežu Srbiji i Crnoj Gori izbori što veću albansku državu, ali su obe delegacije naglašavale da ni pod kojim uslovima ne mogu pristati da Kosovo i Metohija, „svete zemlje srpskog naroda“, ostanu van njihovih granica. Upadi naoružanih arbanaških četa na srpsku teritoriju pod zaštitom turskih i austrougarskih službi tokom 1913. imali su cilj da destabilizuju srpsku upravu u novooslobođenim krajevima, najavljujući skori obračun Austrougarske sa Srbijom, glavnom smetnjom germanskom Drang nach Osten.

Prvi svetski rat omeo je ne samo konsolidovanje srpske vlasti na Kosovu i crnogorske u Metohiji nego i stvaranje unije između dve srpske države. Austrougarska je pomagala revanšističke težnje izbeglih arbanaških vođa i podgrevala planove o stvaranju „Velike Albanije" s Kosovom, Metohijom i zapadnom Makedonijom. Iz Albanije, gde je besneo građanski rat, pod zaštitom austrougarskih vojnih i diplomatskih službi, organizovane su čete sastavljene od arbanaških izbeglica s Kosova i Makedonije, s ciljem da izazovu ustanak na Kosovu i otvore drugi front prema Srbiji. Pašićeva vlada pomogla je u jesen 1914. Esad-pašu Toptanija, pristalicu balkanskog sporazuma i sila Antante, da preuzme vlast u Albaniji i sa njim sklopila dva sporazuma: o vojnoj saradnji i realnoj uniji. U leto 1915. srpska vojska je, po slovu ugovora, vojno intervenisala u Albaniji da zaštiti Esad-pašin režim i slomi ustanak pristalica Trojnog saveza.

\footnotetext{
${ }^{47}$ Skendi, Albanian National Awekening 1878-1912, Princeton, Princeton University Press, 1967, p. 202.

${ }^{48}$ Lj. Jovanović, Srpski narod i otomanska ustavnost, Dositije Obradović, Beograd, 1908. str. 8.
} 
Posle zajedničke austrougarske, nemačke i bugarske ofanzive na Srbiju u jesen 1915. srpska vojska je bila prinuđena da se povlači prema jugu zemlje. Bilo je i planova da se odsudni otpor pruži na Kosovu, ali je, posle presecanja veza sa Solunom, preovladalo mišljenje da je bolje domoći se albanske obale i tamo stupiti u dodir sa savezničkim snagama. Zbog gladi, bolesti, jake zime i sukoba sa arbanaškim plemenima u oblastima gde se nije prostirala vlast Esad-paše, u Albaniji je od 220.000 vojnika zauvek ostalo njih oko 70.000, a od 200.000 civila izbeglica, na Krf i u Bizertu stigla je njih trećina (oko 60.000 ljudi). ${ }^{49}$ Pod austrijskom i bugarskom okupacijom, tokom Prvog svetskog rata, Srbi su bili podvrgnuti novim progonima, pokušajima_denacionalizacije i osvetama: između 1915. i 1918. Albanci i Bugari ubili su 22 srpska jerarha, sveštenika i monaha, uključiv i mitropolita raško-prizrenskog Vićentija.

\section{Literatura}

[1] Bogdanović, D. Knjiga o Kosovu, Posebna izdanja, SANU, DLXVI, Beograd, 1985,

[2] Bogdanović, D. Knjiga o Kosovu, Narodna knjiga i Vojnoizdavački zavod, Beograd, 1999.

[3] Boban, V. Jastrebov u Prizrenu, Jedinstvo, Priština 1983.

[4] Bataković, D. Kosovo i Metohija: Istorijsko nasleđe i geopolitička ograničenja, u Zborniku radova 11. „Kosovo i Metohija izazovi i odgovori“, izd. Institut za geopolitičke studije Beograd 1997.

[5] Bataković, T. D. Kosovo i Metohija u srpsko -albanskim odnosima, Čigoja, Beograd, 2006.

[6] Bataković, T. B. Kosovo i Metohija u srpsko-arbanaškim odnosima, Čigoja, Beograd, 2006.

[7] Bataković, T. D. „Les Français et la Vieille Serbie“, Rapports franco-yougoslaves, Belgrade 1990.

[8] „Velika Albanija - zamisli i moguće posledice, Zbornik radova, izd. „Institut za geopolitičke studije, urednik Jovan M. Čanak, Beograd 1998.

[9] Brailsford, N. H. Macedonia Ils Races and Their Future, London 1906.

[10] Vojvodić, M. Srbija u međunarodnim odnosima krajem XIX i početkom XX veka, SANU, Beograd 1988.

[11] Vidačić, R. „O korenima separatizma i terorizma na Kosovu“ izd. Službeni list SRJ, Beograd, 2000.

[12] Gaćinović, R. Otimanje Kosova i Metohije, Novinsko-izdavački centar „Vojska“, Beograd, 2004.

[13] Dedijer, J. „Stara Srbija, geografska i etnografska slika“, Srpski književni glasnik, XXX, Beograd, 1912.

[14] Dumba, C. Dreibund und Entente-Politik in der Alten und Neuen, Welt, Amalthea Velag 1931.

[15] Đorđević, D. Izlazak Srbije na Jadransko more i Konferencija ambasadora u Londonu 1912. Beograd 1956.

[16] Lutovac, V. M. Glas CCLXXXII Srpske akademije nauka i umetnosti, knjiga 34/1972.

[17] Mitrović, A. Srbija u Prvom svetskom ratu, JP, Službeni glasnik, Beograd, 2014.

[18] Mikić, Đ. Austro-Ugarska i mladoturci 1908-1912, Institut za istoriju, Banja Luka, 1983.

[19] Mikić, Đ. Društvene i ekonomske prilike kosovskih Srba u XIX i početkom XX veka. Od čifčijstva do bankarstva. SANU, Posebna izdanja, knj. DLXXXVIII, Beograd 1988.

[20] Mémorandum sur la situation des Serbes en Macédonie et en Vielle Serbie, „Srpske braće" Belgrade, 1907.

\footnotetext{
${ }^{49}$ Andrej Mitrović, Srbija u Prvom svetskom ratu, JP, Službeni glasnik, Beograd 2014, str. 21.
} 
[21] Memoradnum o Kosovu i Metohiji svetog arhijerejskog sabora srpske pravoslavne Crkve, Beograd, 2003.

[22] Naučni Demografski zbornik: „Naselja i stanovništvo oblasti Brankovića 1455 godine“, urednik akademik M. Macura, Beograd /SANU 2001.

[23] Radonić, J. Rimska kurija u južnoslovenskim zemljama od XVI - XIX veka, Beograd, 1950.

[24] Rakić, M. Konzulska pisma 1905-1911(prir. A. Mitrović), Prosveta, Beograd, 1985.

[25] Stepić, M. Geografske osnove geopolitičkog položaja Kosova i Metohije, U Zborniku, „Kosovo i Metohija - izazovi i odgovori“, izd. Institut za geopolitičke studije Beograd, 1997.

[26] Stulli, B. „Albansko pitanje“, Rad JAZU, 316. Zagreb, 1959.

[27] Stanković, Đ. Đ. „Nikola Pašić i stvaranje albanske države“, Marksistička misao, br. 3, Beograd, 1985.

[28] Stojančević, V. Južnoslovenski narodi u Osmanskom Carstvu od Jedrenskog mira 1829. do Pariskog kongresa 1856. godine, Beograd 1971.

[29] Ćorović, V. Odnosi između Srbije u Austro-Ugarske u XX veku, Državna štamparija kraljevine Jugoslavije, Beograd, 1936.

[30] Ćorović, V. Borba za nezavisnost Balkana, Balkanski institut, Beograd, 1937.

[31] Đilas, K. J. Srpske škole na Kosovu od 1856. do 1912. Studija zajedničkih naučnih ustanova Kosova i Metohije, Priština, 1969.

[32] Cvijić, J. Balkanski rat i Srbija, Beograd, 1912.

[33] F. C. H. I. Pouqueville, Voyage dans la Gréce, II, Paris 1820.

[34] Ferdinand Moore, The Balkan Trail, New York 1906, (reprint 1971) 223.

[35] Hrabak, B. „Arbanaški prvak Isa Boljetinac i Crna Gora 1910-1912", Istorijski zapisi, br. 1, Titograd, 1977. 